\title{
New Materialist Spectatorship: \\ The Moving-Image-Body, the Mockumentary and a New Image of Thought
}

\author{
MIRIAM VON SCHANTZ, Örebro University
}

\begin{abstract}
In this article I propose to rethink spectatorship as analytic category within cinema studies. Through an engagement with new materialist theory I shift the conversation from the locked positions of spectator and text towards an acknowledgement of the spectatorial event as a becoming increased or decreased in capacity to affect and be affected. By doing so I argue that what is effectuated in the event of spectating is in fact the production of a certain body, what I call a moving-image-body. This, I claim, develops in connection with different socalled spectatorial contracts, contracts that produce different agential conditions. An examination of some examples from the realm of the mockumentary, notably I'm Still Here (Affleck, 2010), leads me to discuss the core of the issue as one pertaining to the potential production of new realities, and my methodological proposal as a way towards mapping, not what the event of spectating means, but rather what it does.
\end{abstract}

\section{KEYWORDS}

Spectatorship, Mockumentary, New Materialism, Genre theory, Audiovisual Event. 
'What, then, is Deleuze's spectator? First of all, Deleuze's spectator cannot be said to exist prior to a film. There is no prior "subject" to be posited as existing anterior to the happening of the filmic event [...] Richard Rushton (2009), 'Deleuzian Spectatorship', Screen 50, Spring, 48.

In his Introduction to Documentary, Bill Nichols states that a definition of the documentary, however difficult such a definition would be, is a 'representation of the world we occupy' $(2001,20)$. Moreover, the documentary will be met with a spectatorial assumption that 'the text's sound and images have their origin in the historical world we share' (35). In other words, the spectator assumes that if it is a documentary, its content is not produced solely for the purpose of being filmed; it is a content that in some way exists 'anterior to [...] the filmic event' (Rushton 2009, 48). But is this idea of stable anterior unities a productive approach for investigating cinematic spectatorship? In what way does this "reality" exist anterior to the filmic event, exactly? And does this automatically assume a spectator who equally exists anterior to the filmic event? Can it be so that the spectatorship of films indeed participates in the creation of both the filmic and spectatorial real in such a way that it renders any anteriority irrelevant? To be clear, what I am asking is: In what way can filmic spectatorship be understood as a process of making realities? Whether filmic spectatorship can be considered an agential ordeal, and what this would entail, is thus what is up for discussion.

For studying the agential capacity created in the filmic spectatorship, I believe the spectatorship theory available to date falls short. Here I will offer argumentation as to why I believe this, as well as provide a new methodological tool for use in the analysis of cinematic spectatorship: the concept of the moving-image-body, or mib for short. ${ }^{1}$ In this article I will delineate its diagrammatical function as it displays the 'relations between forces which constitute power [...]' (Deleuze 1999 [1988], 31). Unquestionably, I am not the first to

\footnotetext{
${ }^{1}$ When I began my research I had difficulties coming to terms with the prevalent concept of 'text' in film theory. While recognizing the structuralist legacy of the likes of Roland Barthes, Louis Althusser and Jacques Lacan, I believed that the term had to be abandoned or at least problematized following the insights of the affective turn. Also, with the changing media landscape and the proliferation of innumerable windows of distribution and display for audio-visual content, I felt that my choice of terminology should not lock itself within the location/material specificities of 'film' either, since I believed that whatever a film and other audio-visual content can do is possible for it to do in several locations. But what to use if neither film nor text convened? I opted for the concept of 'the moving-image-text', or mit for short, in order to show that it was something that could be scholarly analysed but did not belong to one single space of distribution. As my research progressed, notably through the full acceptance of new materialist ethico-onto-epistemology (Barad 2007), the concept of the moving-image-body, the mib, was an almost natural progression.
} 
investigate the agency of the spectator. Indeed, this has been the main preoccupation of cinematic spectatorship theory since its conception (Aaron 2007). It can even be said that it has been the tension in the active/passive, reader/receiver debate that has been the driving force of development within the field, placing Roland Barthes' proclamation of "the death of the author" and "the birth of the reader" as the threshold to modern spectatorship theory (Stam 2000, 229, Mayne 1993, 44). As a site for meaning-making, the practice of spectatorship has thus been theorized as a "reading" practice of ideological consequences (Barthes 1970, Baudry 1974, Metz 1975, Comolli 1980, Mayne 1993); consequences that have been theorized as impacting the agential capacity of the spectator. And even though Stuart Hall continued this discussion through his "Encoding/Decoding" (1980) whereby he awarded the spectator (or viewer) a more active position than the previous apparatus theory had done, the spectator was still theorized as a position from which he/she could be influenced to choose to read the text in a more or less agential way.

Another point of entry into spectatorship theory, also centering on the interactive aspect of spectatorship, is the study of genre whereby spectatorship is considered intrinsically tied to the "knowability of the spectator". As expressed by Andrew Tudor, '[...] the crucial factors which distinguished a genre are not only characteristics inherent to the films themselves; they also depend on the particular culture within which we are operating [...]. Genre is what we collectively believe it to be' (italics in original, Tudor 2000, 97,). That a film is considered for instance a documentary, a representation of our shared historical world, is then not a matter of formalism but of reception.

In understanding the spectatorship of films as either a practice of identification (unconscious or conscious) as in apparatus theory or cultural studies, or of recognition as in genre theory, the exterior and anterior world of both the spectator and the screen are viewed according to a humanist transcendental separation of object and subject. In this article, this humanist paradigm will be understood as "representationalism" (Deleuze 2004 [1968], Pisters 2003, Barad 2007, Dolphijn and van der Tuin 2010/2012). As a specific ontological and epistemological realm, representationalism has been the prevailing framework in science and academia at large, and builds on a '[p]hilosophy of representation [that] is based on the idea of a model and a copy (the original and the image, the essence and its reflection)' (Pisters 
$2003,25) .^{2}$ In theorizing spectatorship through representationalism, the very notion of agency is thus considered a dichotomous notion. Someone can have, or not have, agency; and a film can be constructed in such a way as to make a spectator either passive or active.

In order to begin reconsidering the agential capacity of the act of spectating, I believe the above dualist divide needs to be overcome. Instead, spectatorship needs to be theorized as an act of entanglement of screen and spectator. I therefore propose a rethinking of spectatorship through new materialism (Braidotti 1994, Dolphijn and van der Tuin 2010/2012, Parikka 2012). This term refers to an emerging framework for science and the humanities, also called neomaterialism (DeLanda 1996), which is currently gaining strength transversally and from within disciplines as varied as cinema studies, media studies, eco-criticism, architecture and gender studies, to mention just a handful. ${ }^{3}$ As a transversal and rhizomatic framework founded on 'process ontology' (Braidotti, 2006), new materialism shares an 'immanent thought and, as consequence, [it] breaks through not only the mind-matter and culture-nature divides of transcendental humanist thought, but also thinking causal structures and teleology' thus '[r]eworking and eventually breaking through dualisms' as well as 'de-territorializing the academic territories' (italics in original, Dolphijn and van der Tuin 2012, 96-101). Thinking spectatorship through new materialism hence forces a rethinking of agency as a notion. Thus, agency will not be understood as a notion that can be contained in an "either...or" reasoning. Contrarily, agency will be the power of disruption and disorganization, which is what Stephen Zepke calls, the basis for any real creation, that is, any real change (2012). It thus overrides the "either...or" with an "and...and...and".

In order to rethink spectatorship through new materialism, appropriate concepts are hence needed. Here I introduce a new methodological concept, which I call the moving-image-body, or mib for short. The mib enables a conceptualization of the spectator and film as a machinic assemblage, or body of becoming. By sidestepping the analysis of meaning the mib allows us to approach spectatorship as an act or as the creation of an event rather than a "position" or "role", hence unclogging such a coagulated conceptualization. My proposition is therefore a

\footnotetext{
${ }^{2}$ This is what Deleuze calls the 'dogmatic image of thought', see Difference and Repetition (2004), 167.

${ }^{3}$ As the central theoretical node, I would position Gilles Deleuze and Felix Guattari's Capitalism and Schizophrenia project, composed of Anti-Oedipus (1972) and A Thousand Plateaus (1980), which in turn opens up towards the philosophy of Spinoza, Nietzsche and Bergson.
} 
suggestion for how to rethink the 'dynamic duo' of spectator and film as an event of becoming. 4

As the practice of spectatorship is typologically changed from a noun to a verb, the imperative to also adapt the research questions follows. Because when new materialism invites a rereading and re-writing of academia, other 'problems' than what the humanist paradigm allows for will emerge. These will not be of a dichotomous but rather an immanent kind. That is, a new materialist research question will assume that 'the subject is not a priori given, but perception and experience form it. It is by the multiplicity of perceptions that the ' $\mathrm{I}$ ' is formed, the brain being the nervous center of all connections and constructive subject formations [...] [i]n an immanent philosophy, the subject is in constant formation, always changing through multiple encounters' (Pisters 2003, 21-22). As a methodology for the moving image, new materialist film and media methodology must therefore invalidate the idea of individual and separate unity/identity, pointing to the starting assumption that whatever the human (researcher, or in this case, also the spectator) and the 'film text' are, these are produced in entanglement with the elements with which they become affectively connected.

In this article I will present the general composition of the mib and exemplify its function through the mockumentaries This is Spinal Tap (Rob Reiner 1984) and I'm Still Here (Casey Affleck 2010). ${ }^{5}$ Further work on new materialist spectatorship by use of the mib will enable the detailed mapping of the mibs of specific films and the agential capacities that are actualized through the same. Hereby, films previously considered the same through a genre affiliation can henceforth be seen as enabling different events of spectatorship. And in a similar vein, films commonly considered different in terms of genre can in this way be understood as forming similar moving-image-bodies.

\footnotetext{
${ }^{4}$ The event will throughout this text be understood as a singularity which is nothing other than its effects, 'the purely expressed' (Deleuze 1990 [1969]), 149.

5 The terminology of 'mockumentary' is not all together established. In 'Faking What? Making a Mockery of Documentary', Alisa Lebow argues that this is the most adequate term since it "works to signal a scepticism toward documentary realism, rather than to reauthorize documentary's "truth" against the fake doc's "false" $(2006,224)$. Her argumentation stands in contrast to the term used by Alexandra Juhasz and Jesse Lerner, editors of $F$ is for Phony; Fake Documentary and Truth's Undoing, whom employ the term fake documentary. Jane Roscoe and Craigh Hight prefer the term mock-documentary (2001, Roscoe also 2006), although Hight later in Television Mockumentary, Reflexivity, Satire and a Call to Play (2010) abandons this for 'mockumentary'. My choice of terminology affirms Lebows evaluation of this kind of film although I find that, as I will discuss in this article, some mockumentaries do indeed 'reauthorize documentary's "truth" against the fake doc's "false".
} 
Rethinking spectatorship through new materialism enables a move from the signifying universe of genre, whereby "we know what it is because we recognize it as such" towards the Spinozist credo that 'we do not even know what a body can do' (Deleuze 1988 [1970], 1718). This realization - that a body is what it does (and not what it 'means') - prompts the new materialist spectatorship scholar to engage in films from another angle than both apparatus theory and genre theory. Instead of the spectator being 'positioned', he/she is involved in an entangled action. And instead of reading the outcome of this act through meaning (albeit a conscious, voluntary one), the focus is on what agential capacities are enabled in different spectating acts (and how to rethink agential capacities overall).

\section{The mib}

If the act of spectating in effect creates a moving-image-body, what then is a body? A "body", or an assemblage (Deleuze and Guattari 2004, 439-441), is a set of relations of forces produced by its connections, 'largely made through relations with others (italics in original, Hickey-Moody 2013, 83). ${ }^{6}$ This non-anthropocentric body is a pre-individual body; an assemblage of connections or a set of relations between elements (Coonfield 2006, 292-293). These relations are produced affectively. This means that the relations (that constitute, and are constituted by, the body) are produced as a result of a process of actualizing virtuals. Importantly virtuals, or virtualities, are the non-actualized real. ${ }^{7}$ Any body is a specific assemblage, produced by the specific processes of actualization that participate in its production. Intensities, also known as affects, impact this process of actualizing (Massumi 2002, 27), and they do so in such a way that it changes the capacity (power) of a body (Hickey-Moody, 80). ${ }^{8}$ The agency of a body is thus contingent on its capacity to be affected

\footnotetext{
${ }^{6}$ Importantly, this is not a phenomenological body. The new materialist body is a force field of relations that produce a certain doing. The new materialist body is thus a machine or an assemblage, but more importantly, it is what the machine or assemblage can do. As such, it is not subjective, that is to say, necessarily human and individual.

${ }^{7}$ In Difference and Repetition Deleuze explains this through the formula of '(indi)-different/ciation', which explains the entangled process of actualization of the real (350).

${ }^{8}$ Karen Barad's diffractive methodology, through which she introduces the terminology of intra-action, echoes this entangled productivity of matter. In her account, materializations are produced through a process of exclusion, which in turn affect the same. There is thus never 'a meeting of two' as expressed through the wording of "interaction" but always only entangled production - intra-actions. These "reconfigure the possibilities for change' $(2007,182)$.
} 
and to affect! ${ }^{9}$ If we do not know what a body is unless we look at what it does, then we need to look at the capacities of change of the body. These are its agential capacities. Agency is thus not related to what the body is. Agency is not anything anyone has, but something that is done in a relation. And an affect can change a specific body's capacity to change so that it is less or more capable of changing. ${ }^{10}$

A moving image is an assemblage and a spectator is an assemblage, and when a spectator watches a moving image a new assemblage is created: the mib. The moving-image-body is thus a realization of relations and intensive connections, "an evocation of emergence and heterogeneity" (Marcus and Saka 2006, 106); that is, an affecting unfolding of virtuals into singular actuals (Deleuze and Parnet 2002). This means that the spectator enters the mib as a relation between the visible and the stateable, potentially changing these as well as other relations, which all participate in the perpetual unfolding of the mib.

The concept of the mib thus offers itself as a tool for investigating the relations and processes of actualizations of a specific event of spectating. ${ }^{11}$ And as an affective entanglement, the mib and its theoretical application are produced by its connections. Thus, the relations of intensities need to be detailed and investigated in order to know the action (effect and outcome), the agential capacity as it were, of the assemblage. However, the scope of this article limits me here to introducing the concept and exemplifying what it can do by investigating the specific actualization of "reality" in two different mockumentaries. Any further work of detailing the specific relations of specific mibs and what they can produce I leave to future studies. For now, the merit of the mib is that it offers a way to reappraise the agential space that is produced in the spectating event. It thus serves as a "movable bridge" (Deleuze and Guattari 1994, 23). Here, this bridge is inserted as intensity in the body of the mockumentary.

\footnotetext{
${ }^{9}$ As stressed by Karen Barad, this capacity 'to be affected and to affect' lies in fact in response-ability, as in the ability to respond (Dolphijn and van der Tuin, 54f, my italics). Thus, the ethical dimension is intrinsic in a new materialist understanding of the body.

${ }^{10}$ These are the realizations of Spinozist sad passions or joy; see Deleuze, 1988.

${ }^{11}$ As phrased by Ronald Bogue, 'it functions as an experimental protocol whereby the outcome is always specific' (2011, 82-83). This is supported by Deleuze and Parnet's statement, 'the relationship of the actual and the virtual forms an acting individuation or a highly specific and remarkable singularization which needs to be determined case by case" $(2002,152)$.
} 


\section{The mib of This is Spinal Tap; signing the contract}

The mockumentary has been defined as a film that uses the form of a documentary but fills it with fictitious content (Roscoe and Hight 2001, 49). It thus sets up relations of the "real" and the "fake" as coordinates of both spectatorial knowledge and percepts of the Real. The spectator of a mockumentary such as This is Spinal Tap, the mock-rockumentary that chronicles the fake rock band Spinal Tap, has been understood as a 'knowing' spectator, a spectator that recognizes this play between the documentary form and the fictive content. In fact, the very prerequisite for a film to be 'mock' has been posited to be the recognition as such by a knowing audience (Lipkin, Paget and Roscoe 2006, 24). The spectator as a knowing subject is thus one of the main relations set up in the act of spectating what I term the "classical mockumentary". This relation is contained in what I call the spectatorial contract (von Schantz, 2014). ${ }^{12}$ In the only monograph on the subject of the filmic mockumentary to date, Faking it: Mock-Documentary and the Subversion of Factuality (2001), Roscoe and Hight spell out what they call 'the discourse of factuality'. This is an umbrella term that brings together several different discourses: discourses that, according to Roscoe and Hight, underlie the project of the documentary, hence the mockumentary, as it has evolved throughout the history of the moving image, and that describe the specificities of the 'documentary apparatus'. This 'apparatus' is comprised of the discourses of the apparatus as scientific inscription, the apparatus as indexicality, the apparatus as materiality, the apparatus as practice (and here they refer to other practices such as the practice of journalism and the joint project 'to present truthful and honest accounts of the social world.'[14]) and last but certainly not least, the apparatus as reception (6-23).

The contract that is thus offered to the spectator of the mockumentary is a contract in which "the praxis of the real" is playfully deconstructed. The knowability of the spectator is not only a knowability of the specific contract but also of the function of film in constructing the documentary real. This inherent meta-level needs to be recognized by the spectator, for the contract to be accepted in full (Roscoe and Hights, 67). In Spectatorship, The Power of Looking On, Michele Aaron claims that the respective spectatorship of the 'real and the fabricated' only differs through 'opposing kinds of foreknowledge' $(2007,121)$. Indeed, the

\footnotetext{
${ }^{12}$ Drawing from Difference and Repetition I understand a contract as a signal that 'something is to be expected', in other words, as the result of a contracting time-movement. Through the passive synthesis of time Deleuze explicate habit as the drawing something new from repetition, that is to say, by "contracting that from which we come", 94-95. The contract thus explains the contracting of habit and memory of the spectator.
} 
heart of the matter seems to be that the ontological status of documentary film in relation to reality does not actually differ from that of the fiction film, pointing towards the difference between the fictive and the factual as founded not on the characteristics of form or content but rather on '[... ] specific systems of expectation and hypothesis which spectators bring with them to the cinema, and which interact with films themselves during the course of the viewing process' (Neale 1990, 46). ${ }^{13}$ Political theorist Davide Panagia states that 'the first political act is also an aesthetic one, a partition of sensation' (Panagia 2009, 9). The practice of genre is thus an epistemological order that underpins a parting of the sensible, making certain contracts appear natural. Interrupting this ordering of the senses would then point towards a political act in that it disturbs the biopolitical system of production and reproduction of subjectivities, which depends on the discourse of factuality and the practice of genre as the backdrop-of-the-real (Zepke 2011, 206). The first conclusion is thus that the difference between the factual and the fictive is a matter of reception, and that this reception is guided by a contract whose epistemology carries political implications.

In This is Spinal Tap, formal requirements of the discourse of factuality are used in constructing the story of the fictive rock band 'Spinal Tap'. The technique of using interviews, talking heads and direct address, as well as sequencing 'the ordinary events in a day' of the members of Spinal Tap and parodying sequences from the famous rockumentary Don't Look Back (D.A. Pennebaker, 1967) which portrays Bob Dylan on his 1965 tour of England, together compose an address of the spectator; that is, offer a contract that "asserts that what it presents is much like what we conventionally see in documentary" (Lipkin, Paget and Roscoe 2006, 23). Much like - not the 'real deal'. This contract thus begins as the spectator starts his/her 'inferencial walk' whereby he/she draws conclusions regarding what he/she is seeing based on previous knowledge (Eco 1984, 32). In this way, the spectator is always already present in the film since it becomes through the practice of reception. The film, whether fiction or documentary, enacts a series of persuasive acts in order to realize the spectatorial contract. With regard to the mockumentary, there is thus a playful persuasion concerning the 'documentary' (as formulated through the discourse of factuality) in order to assert that it is actually not a documentary proper. When this persuasion is received as such and accepted as legitimate, as is done in the case of This is Spinal Tap, the mockumentary

\footnotetext{
${ }^{13}$ By comparing documentary and fiction film on the basis of Metzian syntax, Kees Bakker proves that the same syntagmas are present in film on 'both sides' of the documentary/fiction divide: http://kees.bakker.pagespersoorange.fr/docufiction.htm (retrieved 140408).
} 
contract is signed. Roscoe and Hight (2001) classify the mockumentary in three degrees ranging from parody in degree 1 , through critique and hoax in degree 2 to deconstruction in degree 3. Whereas a degree 1 mockumentary such as This is Spinal Tap makes obvious its fictional nature, a degree 3 mockumentary displays a higher degree of medium-reflexivity. Here the documentary form itself is the main subject and it does not, as in a degree 1, mock contemporary culture or a well-known cultural phenomenon, for instance Bob Dylan, rather it is the documentary project as such which is deconstructed. But whatever the 'degree', the contract is a mock contract as long as its fictional nature (even though it might range from obvious to discrete) is received. This happens in the case of the degree 3 mock Man Bites Dog (Belvaux, Bonzel and Poelvoorde, 1992), a detailed deconstruction of the formal codes of the observational mode known through the direct cinema movement (referred to by Roscoe and Hight as the documentary apparatus as practice). Here, the spectator recognizes the aesthetics of the "fly on the wall", but at the same time, the interaction of the film crew with a murderer on a rampage whereby they end up joining in (!) is so unbelievable and exaggerated, thus signaling the humorous play with this aesthetic (Roscoe and Hight 2001, 171-178). Even though a spectator might accept the documentary contract at first, by the end of the film there is no choice but to either accept the mock contract or bring the film to court as a snuff movie. $^{14}$

The mockumentary hence constructs a contract that rests on the epistemological assumption of the 'false' in relation to the 'real'. Even though the most reflexive degree 3 mockumentaries deconstruct how the real is 'made', they do not deconstruct the notion of 'the real' as a representationalist and humanist notion of externality and transcendence (Colebrook $2010,100)$. The mib created through the act of spectating a classical mockumentary is thus a body of virtualities (of the real) actualized as intensities of realness and falsity, neatly posited in their respective representationalist cages while reducing the spectatorial agential capacity to an "either...or" logic. In other words, even though the deconstruction of the formal qualities of the documentary real in This is Spinal Tap or Man Bites Dog could at first be considered a critical practice (through their displaying and deconstruction of the discourse of factuality), its reception as such lies in its recognition. That is, it has to be recognized as a fake that is playing with "the real" in order to offer the mock contract. In so doing,

\footnotetext{
${ }^{14}$ As happened in the case of Cannibal Holocaust (Ruggero Deodato 1980), in which the director was forced to show the actors in court lest he be accused of murder; http://www.theguardian.com/film/2011/sep/15/cannibalholocaust (retrieved 140408).
} 
paradoxically, the open and rhizomatic potentials of a becoming-real are organized and stratified. Deleuze and Guattari call this a 'phenomenon of accumulation, coagulation, and sedimentation that, in order to extract useful labor [of the Body without Organs, from now on called $\mathrm{BwO}]$, imposes upon it forms, functions, bonds, dominant and hierarchized organizations, organized transcendences' $(2004,176)$. The intensities of the real are thus turned into organs which are organized on the body. This sedentary organization of the territory of the real in the classic mock-mib is indeed the making of a "face" whereby the potentials of the real are stabilized and contained, breaking the line of flight, or in more accurate terms, coagulating the leakage of the body (the virtualities of becoming of the BwO). ${ }^{15}$

\section{The mib of the affective mockumentary; a contract to come}

In using the idea of a contract as a point of entry into thinking the agential capacity of a film, I realized that there are films that use the form of the factual together with a fictive content thus mockumentaries as defined in the existing literature - but that still do not offer the contract of the mockumentary. Instead of offering a playful deconstruction of the discourse of factuality, which would re-instate a "real-real" as opposed to its own "fake-real", these films seem to adamantly stick to the documentary contract although they later, often through confessions in the news media, turn out to be mockumentaries. The conclusion must be that they are either "lying" or in fact pointing to a re-evaluation of the documentary contract, that is, offering a leakage onto the representationalist perspective on the ontology of the audiovisual real, as it were. Through the concept of the mib it will become clear that my proposal is to consider the latter alternative, not least since this concept completely bypasses any "intention" and instead only focuses on the action proper.

In the slim literature on the mockumentary, this sub-group in the mock corpus has been identified as "the hoax" (suggesting that thus far they have been considered to be "lying"). Examples given in Faking it are Alien Abduction (Dean Alioto 1998) and Forgotten Silver (Costa Botes and Peter Jackson 1995). Others have suggested the "News on the March" reel

\footnotetext{
${ }^{15}$ In a discussion with Barbara Glowczewski in the 8th Deleuze Camp, Istanbul 2014, the terminology of the English translation of 'line of flight' (french: ligne de fuite) was raised. This translation of the french 'fuite' (leakage) into 'flight' misses the liquid quality of the disruptive force of virtualities that can appear on the facialized body. In this text I therefore think leakage where I previously would have line of flight.
} 
that opens Citizen Kane as an early predecessor (Bayer 2006), and I would suggest later examples to include I'm Still Here and Exit Through the Gift Shop (Banksy 2010).

Thinking with new materialism enables a re-evaluation of this idea of a "lie". If we only know what a body is by looking at what it does, we clearly need to understand that the documentary contract of these films, which do not have "legitimate" factual content to go with such a contract, makes them do something different. This is also why a different terminology for these films is called for. I here offer the term of affective mockumentary, since this type of film enables a mib of an affective disruption of the real in such a way as to produce a new image of thought. Panagia argues that we need to regard the political act as one of rendering perceptible what had been previously insensible which would invalidate the act of recognition as a political act $(2009,151)$. If we recognize a thing, we already know what it is. It is not an "unknown" that is in the becoming-known; it is a known confirmed to be so. Thus, rather than recognition, a true political act is a rendering unrecognizable since this would indicate the process of making known that something is not as we previously knew it. The affective mockumentary offers an unrecognizable contract, thus forcing the spectator to engage with the film beyond the issue of truth/falsity. Instead, the affective mockumentary (or should I call it documentary?) breaks down the apparatus of the documentary, ushering the spectator into a mode of new materialist spectatorship ${ }^{16}$. Such a spectatorship develops along a line of leakage that allow an entry to 'the people that are missing' to come (Deleuze 1985, 208). Deleuze's "missing people" are the potentialities of future realities that are produced in affective entanglement through the mib of the affective mockumentary. Instead of considering the spectator a separate entity, an individual who is influenced through his/her identification with representations - as does the mib of This is Spinal Tap as it establishes a spectator who "knows the true from the false" - the mib created through the affective mockumentary allows for the spectator-screen-body to participate in the production of life, to enter a process of becoming real, as it were.

Thus, the affective mockumentary functions by parasitic logic (Pasquinelli 2008), emerging as an excessive and intensive event that parasites the discourse of factuality in order to create

\footnotetext{
${ }^{16}$ This can also be called schizoanalytical spectatorship, since the schizoanalysis of Deleuze and Guattari is indeed a new materialist method. As a matter of legibility I stick to the overarching terminology of new materialism, but for the sake of exactitude I want to underline that I count schizoanalysis as one of the most fruitful new materialist contributions, if not the most central, thus making my suggestion for a new materialist spectatorship equal to a suggestion for a schizoanalytical spectatorship.
} 
new forms of production of the social, the subjective and the real (Zepke 2012, 222). The "documentary contract of the affective mockumentary" is not one of giving answers pertaining to the real and the false. Instead, it is a contract of disrupting the notion of a stable and external "objective" real altogether, instead performing a space for a new real to come, potentializing a new image of thought. The unrecognizable documentary/mockumentary contract is thus actually a "missing contract". It is a contract yet to come.

The political nature of the partition of the sensible, as discussed by Panagia (as well as by Rancière 2000), is thus brought to the fore through the mib of the affective mockumentary, offering the spectator an entrance 'to attend to the world' (Panagia 2009, 19-20). Thus the change of terminology, from "hoax" to affective mockumentary, and the subsequent shift from a lie (negative) to a thought-experiment (affirmation). While the classical mockumentary as I have discussed de- and then reterritorializes the discourse of factuality, it still - through the mock contract - reaffirms the transcendental viewing subject of representationalism. In other words, it organizes the body of knowledge of the real in order to 'lock down' the potentials of the real. Such an organization in fact also 'locks down' what it is that the spectator 'can do'. The spectator is thus no longer a set of potentialities, of immanent emergence; but rather a face, an organized body whereby the action is programmed by its organization (this is real/this is false). The affective mockumentary, on the other hand, reconfigures not only the formative production of the audio-visual real, but also more specifically the agential capacity of the spectator, thus foregrounding the act of spectating as a site for immanence and the production of the future real. In effect, the mib of the affective mockumentary I'm Still Here produces what Deleuze and Guattari call a BwO (2004, 169171). This is a field of immanence, that is, a body of virtuals. By deterritorializing the spectator as a "knower of the real", the mib of the affective mockumentary create leakages onto the face-machine, making it an event of responsiveness for the spectator, a becomingbody-without-organs, as it were. The specific mib of the affective mockumentary reconfigures the spectator, questioning its ontology as a transcendental subject through an opening up to a becoming-body-without-organs. In short, the mib of the affective mockumentary is a body of becoming. A mibwo as it were. 


\section{I'm Still Here; creating a mibwo}

As an affective mockumentary, I'm Still Here offers the "missing contract". It details the life of actor Joaquin Phoenix as he decides to quit acting and start a career as rapper artist J.P. The film premiered on the September 6, 2010 as a documentary out of competition at the $67^{\text {th }}$ Venice International Film Festival. It took a bit more than a week, until September 17, 2010, for director Casey Affleck to come out in the New York Times saying it had been a performance; that they had "wanted to create a space" where '[y]ou believe what's happening is real'. All the same, he adamantly stated that it had not been a hoax. ${ }^{17}$

The missing contract of I'm Still Here is initially set up by following the same protocol as most mockumentaries; that is, the protocol of the documentary. Here, the discourse of factuality is key in establishing the film as rooted in "the praxis of the real". The first sequence is shot "home-video" style, complete with the date on-camera as well as the grainy quality of the camcorder and a prevalent shaky amateur camera. This reliance on the discourse of factuality brings out the relation of the camera to the mundane and ordinary event of recording-a-day-in-the-life. The opening of the film continues with an appeal to the spectatorial foreknowledge of famous television hosts and Hollywood actors. In a fast-paced editing sequence, the spectator is presented with excerpts from celebrity TV shows - The Tonight Show with Jay Leno, Late Night with Conan O'Brian and The Late Show with David Letterman - as well as red-carpet events, all featuring award-winning actor Joaquin Phoenix. This editing sequence is abruptly ended when there is a cut to a dark location, solely lit by a single bulb, overlooking Los Angeles in the distance. The camera seems to be handheld, and the back of someone's head is shown on camera, a bit too close, making it a poor-quality shot. As the person starts to talk it appears to be a man, and a while later, this person is revealed as Joaquin Phoenix. His handsome appearance from the red carpets and the TV shows is now exchanged for a gritty, wild, bearded, tired look. As Phoenix starts to speak to the camera about why he "agreed to make this documentary", the aim of the film is spelled out: "to tell the truth' is his promise to the spectator. This ends the prologue and sets the stage for the rest of the film, where this promise seems to be complied with in full. As the film progresses, what is on offer is indeed 'the reality' of this famous person through his everyday life and his pursuit of a career as the rapper J.P. This argument is backed by Phoenix appearing as J.P. at

\footnotetext{
${ }^{17}$ http://www.nytimes.com/2010/09/17/movies/17affleck.html?_r=0 (accessed 140408).
} 
numerous public events throughout the years it took to film I'm Still Here. The contract that is offered is thus clearly the documentary contract. The film is composed of the formal qualities of the documentary, making it consistent with both the doc and mock contracts, but the material world on display is consistent with the documentary contract. Joaquin Phoenix is not made up for the film; he clearly existed before, and his career as a rapper is an affair that is monitored by the news media of the world. It should therefore be considered a documentary contract. And as the film progresses, the playful cues that would let the spectator sign the mockumentary contract are not provided. Nowhere does the film display the recognizable mockumentary trait of the parody and irony of This is Spinal Tap or Man Bites Dog (Campbell 2007). There is simply a continuation of the documentary contract, even though the reality is somewhat of an "excessive reality". The camera is a bit too "home-video", the activities of Phoenix on display overly vulgar and intimate (prostitutes, drugs and pornography), and his descent into madness and chaos a bit too well-played, as it were. It is a form of de-familiarization (Dophijn and van der Tuin 2012, 35) of the safe position of the spectator as a knower. As a film rooted in our shared historical world, using the formal conventions of the discourse of factuality, there is no legitimate reason to claim that I'm Still Here is "fake"; it is as "real" as Don't Look Back or Nanook of the North (Robert Flaherty 1922). A reality as poignant as that in Capturing the Friedmans (Jarecki 2002), Man on a Wire (James Marsh 2008) or Jiro Dreams of Sushi (Gelb 2012). The relation of the real to the false is blurred through the affective unrecognition of the spectator. It is not a question of whether this film is real, but rather of what kind of reality it enables, what mib it allows.

As I'm Still Here comes to a close it is still not playfully comical, instead it produces a pervasive effect of laughter-stuck-in-throat. It stays just at the brink of the bearable, bearable enough to believe but sufficiently unbearable to pry open an affective and ethical space of forming a mib whereby the relations of the real need to be re-evaluated and opened to the fluidity of becoming. The rupture or disturbance of the missing contract, the refusal to offer recognition and knowledge - as potentialized through I'm Still Here - is the point of Barthesian punctum, the moment of 'turning our attentions and a reconfiguration of those correspondences that mediate our worldly interactions' (Panagia 2009, 154). It is in fact what makes it a moving-image-body-without-organs, or a mibwo. Disrupting the relation of certainty and recognition it ushers the spectator into a state of becoming-animal, alert and 
weary in its tracks. ${ }^{18}$ Through the conceptual realization of the mibwo, spectatorship is thus shown as a process of interruption that de-organizes the organization of the body and opens it up to a new image of thought, a becoming-body without organs (Deleuze and Guattari 2004 [1980], 177).

So at the end of the day it is not what is true on film that becomes important but rather what contract which mib enables. I argue that the contract as a communicative act is not in itself an agential capacitor, but that it is the affective and entangled intra-action of the mib that enables certain contracts with in turn different agential potential. This conclusion points to a need to question the whole idea of disentangled and dichotomist spectatorship scholarship, which relies on categories such as truth/falsity, object/subject, real/false and spectator/text. Thinking spectatorship through new materialism exposes the politics of the sensible and the ontological assumption of the real as a definitive external, linear and anterior 'real', thus pointing to the world and ourselves as being in perpetual creation. The missing contract produced in the mib of an affective mockumentary such as I'm Still Here offers a new image of thought, bringing forth the missing people; that is, the becoming real of the spectator. A real that is not yet produced. Still to come. Open. Instead of providing answers that can serve as catalogues (this is real, this is fake, this is a documentary, this is a mockumentary, this is political, this is not...), what is made possible through the formation of the mibwo of I'm Still Here is an affective reconfiguration of the real-event of spectating itself. ${ }^{19}$

The moving-image-body as an analytical tool can thus facilitate an analysis of the specificities of particular acts of spectating; that is, what image of thought with what agential capacity that are actualized. In other words, the mib enables a scholarly move from what a film comes to mean to the spectator to what it is that "the body can do".

\footnotetext{
${ }^{18}$ The becoming-animal is in A Thousand Plateaus the expression of a minoritarian politics, "accompanied [...] by a rupture with the central institutions that have established themselves or seek to become established", 272273.

${ }^{19}$ The mibwo can clearly be any sort of BwO. Deleuze and Guattari speaks of 'the three body problem' which delineates different BwOs (see 2004, 181). These can be cancerous, neurotic, empty or full. I argue that in a similar vein different mibwos functions according to different passions. The scope of this article doesn't allow me to venture further into discussing the specific mibwo that I'm Still Here potentializes, but in my doctoral dissertation I offer a lengthy discussion of different mibs and mibwos within the mockumentary corpus.
} 


\section{References}

Aaron, M. (2007) Spectatorship, the Power of Looking On, Colombia: Wallflower Press

Barad, K. (2007) Meeting the Universe Halfway, Quantum Physics and the Entanglement of Matter and Meaning, Durham and London: Duke University Press

Barthes, R. (1975 [1970]) S/Z, trans. R. Miller, New York: Farrar, Strauss, Giroux

Baudry, J. (1974-1975) 'Ideological Effects of the Basic Cinematic Apparatus', Film Quarterly, 28, Winter, 39-47

Bayer, G. (2006) 'Artifice and Artificiality in Mockumentaries', in G. D. Rhodes and J. P. Springer (eds), docufictions: Essays on the Intersection of Documentary and Fictional Filmmaking, Jefferson: McFarland \& Company, pp. 164-178

Bogue, R. (2011) 'Deleuze and Guattari and the Future of Politics: Science Fiction, Protocols and the People to Come', Deleuze Studies supplement, 5, 77-97

Braidotti, R. (1994) Nomadic Subjects: Embodiment and Sexual Difference in Contemporary Feminist Theory, New York: Columbia University Press

Braidotti, R. (2006) 'Posthuman, all too Human: Towards a New Process Ontology', Theory, Culture and Society, 23, December, 197-208

Campbell, M. (2007) 'The Mocking Mockumentary and the Ethics of Irony', Taboo: The Journal of Culture and Education, 11, Spring-Summer, 53-62

Colebrook, C. (2010 [2002]) Gilles Deleuze - en introduction, trans. V. Andreasson and M. Müller, Göteborg: Bokförlaget Korpen

Comolli, J. (1985 [1980]) 'Machines of the Visible', in G. Mast and M. Cohen (eds), Film Theory and Criticism, New York: St. Martin's Press, pp. 741-760

Coonfield, G. (2006) 'Thinking Machinically, or, the Techno-aesthetic of Jackie Chan: Toward a Deleuzian-Guattarian Media Studies', Critical Studies in Media Communication, 23, 4, 285-301

Deleuze, G. (2005 [1985]) Cinema 2, trans. H. Tomlinson and R. Galeta, London: Continuum

Deleuze, G. (2004 [1968]) Difference and Repetition, trans. P. Patton, London: Continuum

Deleuze, G. (1999 [1988]) Foucault, trans. S. Hand, London, Continuum

Deleuze, G. (1988 [1970]) Spinoza: Practical Philosophy, trans. R. Hurley, San Francisco: City Light Books 
Deleuze, G. (1990 [1969] The Logic of Sense, trans. M. Lester and C. Stivale, New York: Colombia University Press

Deleuze, G. and F. Guattari (2009 [1972]) Anti-Oedipus, trans. R. Hurley, M. Seem and H. R. Lane, London: Penguin Books

Deleuze, G. and F. Guattari (2004 [1980]) A Thousand Plateaus, trans. B. Massumi, London, New York: Continuum

Deleuze, G. and F. Guattari (1994 [1991]) What is philosophy? trans. H. Tomlinson and G. Burchill, London, New York: Verso

Deleuze, G. and C. Parnet (2002 [1977]) 'The Actual and the Virtual', in Dialogues, trans. E. R. Albert, New York: Colombia University Press, 149-159

Dolphijn, R. and I. van der Tuin (2012) New materialism: Interviews and Cartographies, Open Humanities Press

Eco, U. (1984) The Role of the Reader, First Midland Book Edition

Hall, S. (1980) 'Encoding/decoding', in S. Hall (ed), Culture, Media, Language, New York: Routledge, pp. 128-138

Hickey-Moody, A. (2013) 'Affect as Method: Feelings, Aesthetics and Affective Pedagogy', in R. Coleman and J. Ringrose (eds), Deleuze and Research Methodologies, Edinburgh: Edinburgh University Press, pp 79-95

Lebow, A. (2006) 'Faking What? Making a Mockery of Documentary', in A. Juhasz and J. Lerner (eds), $F$ is for Phony, Fake Documentary and Truth's undoing, Minneapolis: University of Minnesota Press, pp. 223-237

Lipkin, S. N., D. Paget and J. Roscoe (2006) 'Docudrama and Mock-Documentary: Defining Terms, Proposing Canons', in G.D. Rhodes and J.P. Springer (eds), docufictions: Essays on the Intersection of Documentary and Fictional Filmmaking, Jefferson: McFarland \& Company, pp 11-26

Marcus, G. E. and E. Saka (2006) 'Assemblage', Theory, Culture \& Society 23, May, 101-106

Massumi, B. (2002) Parables for the Virtual, Durham and London: Duke University Press

Mayne, J. (1993) Cinema and Spectatorship, London, New York: Routledge

Metz, C. (1975) 'The Imaginary Signifier', Screen, 16, Summer, 14-76

Neale, S. (2000) 'Questions of Genre', Screen, 31, Spring, 45-66

Nichols, B. (2001) Introduction to Documentary, Bloomington: Indiana University Press 
Panagia, D. (2009) The Political life of Sensation, Durham: Duke University Press

Parikka, J. (2012) 'New Materialism as Media Theory: Medianatures and Dirty Matter', Communication and Critical/Cultural Studies, 9, 1, 95-100

Pasquinelli, M. (2008) Animal Spirits: A Bestiary of the Commons, Rotterdam: NAiPublishers / Institute of Network Cultures

Pisters, P. (2003) The Matrix of Visual Culture: Working with Deleuze in Film Theory, Stanford: Stanford University Press

Rancière, J. (2000) Le Partage du Sensible, Paris: La Fabrique Editions

Roscoe J. and C. Hight (2001) Faking it. Mockumentarys subversion of factuality, Manchester: Manchester University Press

Rushton, R. (2009) 'Deleuzian Spectatorship', Screen, 50, 1, 45-53

Stam, R. (2000) Film Theory; an Introduction, Malden, Oxford: Blackwell Publishing

Tudor, A. (2000) 'Critical method...Genre', in J. Hollows, P. Hutchings and M. Jancovich (eds), The Film Studies Reader, London, New York: Oxford University Press

van der Tuin, I. and R. Dolphijn (2010) 'The Transversality of New Materialism', Woman: A Cultural Review, 21, 2, 153-171

von Schantz, M. (2014) 'Dokumentärfilm', in Malena Janson (ed), Introduktion till Filmpedagogik, Malmö: Gleerups

Zepke, S. (2011) 'From Aesthetic Autonomy to Autonomist Aesthetics: Art and Life in Guattari', in E. Alliez and A. Goffey (eds), The Guattari Effect, New York: Bloomsbury Academic, pp 205-219

Zepke, S. (2012) 'Art and the Aesthetics of the Interface; Autonomy, Sensation and Biopolitics', in R. Braidotti and P. Pisters (eds), Revisiting Normativity with Deleuze, London, New York: Bloomsbury, pp 218-232

\section{Internet}

Bakker, K. http://kees.bakker.pagesperso-orange.fr/docufiction.htm, retrieved 140408

DeLanda, M. (1996) 'Interview by Konrad Becker and Miss M'. At Virtual Futures 96 Conference, Warwick University, UK, May

http://www.t0.or.at/delanda/intdelanda.htm, retrieved 140425

http://www.theguardian.com/film/2011/sep/15/cannibal-holocaust, retrieved 140408 
http://www.nytimes.com/2010/09/17/movies/17affleck.html? r=0, accessed 140408

\section{Filmography}

Alien Abduction, Dean Alioto, 1998.

Cannibal Holocaust, Ruggero Deodato, 1980.

Capturing the Friedmans, Andrew Jarecki, 2002.

Citizen Kane, Orson Welles, 1941.

Don't Look Back, D.A. Pennebaker, 1967.

Exit Through the Gift Shop, Banksy, 2010.

Forgotten Silver, Costa Botes and Peter Jackson, 1995.

I'm Still Here, Casey Affleck, 2010.

Jiro Dreams of Sushi, David Gelb, 2012.

Man Bites Dog, Rémy Belvaux, André Bonzel and Benoît Poelvoorde, 1992.

Man on a Wire, James Marsh, 2008.

Nanook of the North, Robert Flaherty, 1922.

This is Spinal Tap, Rob Reiner, 1984.

Doctoral student in media and communication and a cinema studies scholar, Miriam von Schantz's research proposes a new materialist methodological framework for spectatorship studies. The insights gained are also employed in addressing the issue of cinema literacy as a didactic method, lastly by contributing a chapter on the documentary film in a book on cinema literacy geared towards the Swedish teachers program. She teaches documentary and general film theory and media history.

Email: miriam.von-schantz@oru.se 